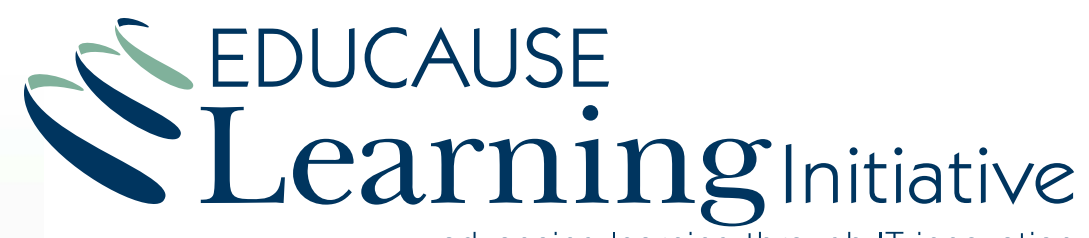

advancing learning through IT innovation

\title{
An Overview of E-Portfolios
}

by George Lorenzo and John Ittelson

Edited by Diana Oblinger

ELII Paper 1: 2005

July 2005

\begin{abstract}
E-portfolios are a valuable learning and assessment tool. An e-portfolio is a digitized collection of artifacts including demonstrations, resources, and accomplishments that represent an individual, group, or institution. This collection can be comprised of textbased, graphic, or multimedia elements archived on a Web site or on other electronic media such as a CD-ROM or DVD. An e-portfolio is more than a simple collection-it can also serve as an administrative tool to manage and organize work created with different applications and to control who can see the work. E-portfolios encourage personal reflection and often involve the exchange of ideas and feedback.
\end{abstract}

Three types of e-portfolios are described in this report: student e-portfolios, teaching e-portfolios, and institutional e-portfolios. E-portfolios can support student advisement, career preparation, and credential documentation; the sharing of teaching philosophies and practices; department and program self-studies; and institutional and program accreditation processes. This report defines and categorizes e-portfolios, offers examples of higher education e-portfolio implementations, reviews e-portfolio technology, and addresses adoption issues. 


\section{Introduction}

E-portfolios ${ }^{1}$ have the potential to enhance teaching, learning, and assessment practices. They can also support

- student advisement and career preparation,

- student or alumni credential documentation,

- sharing of teaching philosophies and practices,

- department and program self-studies, and

- institutional and program accreditation processes.

This report defines and categorizes e-portfolios, offers examples of higher education e-portfolio implementations that illustrate current practice and future potential, and reviews e-portfolio technology, including adoption issues and challenges.

\section{Defining E-Portfolios}

What is an e-portfolio? An e-portfolio is a digitized collection of artifacts, including demonstrations, resources, and accomplishments that represent an individual, group, community, organization, or institution. This collection can be comprised of text-based, graphic, or multimedia elements archived on a Web site or on other electronic media such as a CD-ROM or DVD.

An e-portfolio is more than a simple collection, however; it can also serve as an administrative tool to manage and organize work created with different applications and control who can see or discuss the work. The benefits of an e-portfolio typically derive from the exchange of ideas and feedback between the author and those who view and interact with the e-portfolio. In addition, the author's personal reflection on the work inside an e-portfolio helps create a meaningful learning experience. ${ }^{2}$

E-portfolios can also be defined as "personalized, Web-based collections of work, responses to work, and reflections that are used to demonstrate key skills and accomplishments for a variety of contexts and time periods." ${ }^{3}$ While it is impossible to precisely determine how many institutions have adopted e-portfolio systems, their adoption continues to grow. ${ }^{4}$

\section{E-Portfolio Categories}

When describing the many uses of e-portfolios, three broad categories emerge: student e-portfolios, teaching e-portfolios, and institutional e-portfolios. E-portfolios have six major functions. They are used to

- plan educational programs;

- document knowledge, skills, abilities, and learning;

- track development within a program;

- find a job;

- evaluate a course; and

- monitor and evaluate performance. ${ }^{5}$

Numerous e-portfolio models combine these categories and functions. A student e-portfolio, for example, can be used to showcase accomplishments. It may be shared with a prospective employer or used to document specific learning outcomes in a course and can include description, rationale, 
and discussion of digitized artifacts, resulting in a powerful tool for representation, reflection, and revision. ${ }^{6}$

A teaching e-portfolio can be used in a similar fashion, to showcase a faculty member's accomplishments for career-related purposes. It can also be a collection of course- or disciplinerelated plans, strategies, and artifacts to be shared with colleagues, which often promotes improved teaching and learning. At the broadest level, student and teaching e-portfolios can be aggregated into an institutional e-portfolio containing a wide variety of digitized representations that provide evidence for self-study and accreditation.

\section{Student E-Portfolios}

Student e-portfolios were born out of faculty-assigned, print-based student portfolios dating back to the mid-80s (typically in art-related programs and in disciplines with significant writing components, such as English and communication studies) and gained prominence in higher education during the mid-90s. In the printed mode, as well as in today's electronic mode, students basically collected their work, selected examples to showcase, and reflected on what they learned. ${ }^{7}$

Student e-portfolios are now most prevalent in college of education programs. Preservice teachers use them to provide evidence of competencies required to gain teaching licensure or certification. Student e-portfolios are gaining ground in general education courses where they can reveal skill levels and competencies in such areas as communications, math, or leadership. Other disciplines such as business, nursing, architecture, and engineering are also using them to record students' learning experiences and skill sets.

In general, e-portfolios are helping students become critical thinkers and aiding in the development of their writing and multimedia communication skills. E-portfolios can help students learn information and technology literacy skills and how to use digital media. ${ }^{8}$ Beyond academic evidence, they give students the opportunity to create a digitized showcase of their work and skills that can be presented to prospective employers. Some career services offices are providing an e-portfolio tool to students (and more recently to alumni). These e-portfolios may link students to their alma mater after graduation, provided they receive temporary or lifetime access to their e-portfolios housed on the institution's servers. This can be a free or fee-based (typically through alumni membership) alumni service, depending on the institution.

\section{Issues and Challenges of Student E-Portfolios}

A number of issues and challenges are associated with student e-portfolios.

- Should an e-portfolio be an official record of a student's work?

- Is a student e-portfolio considered an official representation of a particular learning experience or skill achievement of a student?

- If an e-portfolio does not include a professional evaluation, should it be an official document?

- If the student is allowed to update or change the e-portfolio, is it still "official"?

- As e-portfolios accumulate year after year, more servers and maintenance are required. How long should an e-portfolio remain at an institution after the student graduates?

- Should students be allowed lifetime access to e-portfolios after they graduate? 
- Should students be notified of a specific time period (for example, six months to a year after graduation) in which they have the opportunity to transfer their e-portfolio data to some other format, or lose it?

- Should alumni be charged a fee to keep their e-portfolios on an institution's servers?

Who owns the e-portfolio?

- Does the institution providing the e-portfolio system own certain elements of a student's archived work, similar to other college records?

- If the e-portfolio is a document management system for archiving course assignments, who owns and controls the access to such documents and when? At what point is the document owned by a student or faculty member? ${ }^{9}$

- Should anyone other than the student be able to make changes to the student's e-portfolio?

- How should an institution promote and support the use of e-portfolios?

- How do you create a culture in which educators and students understand how to map their learning experiences together to facilitate an effective student e-portfolio system that is a learner-centered, developmental, and reflective aid ${ }^{10}$

- If the e-portfolio is used primarily as a job-finding tool, how do you create a careeradvisement-focused culture and establish the necessary promotional and support infrastructure?

- Should you consider promoting and supporting a combination learner-centered and careeroriented e-portfolio system through faculty, administration, and career-services staff?

- How are e-portfolios evaluated in a manner that is both valid and reliable ${ }^{11}$

- When assessment portions of e-portfolios are tied to artifacts/student accomplishments that relate to predefined standards, who validates the artifact as a student's authentic work? What rubrics are used for deciding how the artifact actually meets a specific standard?

- Does the use of an e-portfolio solely to document a student's attainment of standards narrow its use to the point that it does not support deep learning or an environment of reflection and collaboration ${ }^{12}$

- How can institutions encourage critical reflection in the design and use of e-portfolios? ${ }^{13}$

- What instruction is required so that e-portfolios become part of a reflective learning and assessment process?

- Should curricula require learners to use the portfolio in completing their course work and assignments?

- Should students be provided with advising sessions evaluating their effective use of portfolios? ${ }^{14}$

\section{Teaching E-Portfolios}

Teaching e-portfolios derive from paper-based teaching and course portfolios. Like student e-portfolios, teaching e-portfolios can serve as documentation of skills and accomplishments for career advancement. Teaching e-portfolios are also used for critical reflection and learning purposes; they make individual teaching practices public and therefore available for collective learning and knowledge sharing. ${ }^{15}$

Faculty members sometimes create e-portfolios to introduce themselves and showcase their accomplishments to students, as well as to share ideas inside a class or other community. These 
types of teaching e-portfolios may be a collection of a faculty member's best instructional work and may include such items as teaching philosophy, list of courses taught, lesson plans, and any special recognition or awards received. ${ }^{16,17}$

One example of teaching e-portfolios comes from the Knowledge Media Lab (KML) at the Carnegie Foundation for the Advancement of Teaching and Learning (http://www.carnegiefoundation.org/KML/KEEP/index.htm). KML has promoted teaching e-portfolios through its Knowledge, Exchange, Exhibition, and Presentation (KEEP) toolkit, which is a free, Webbased e-portfolio system used by higher education faculty and K-12 teachers from all over the world. KEEP "makes teaching public" and demonstrates "how faculty can organize, share, and collectively advance their teaching knowledge" by creating dynamic e-portfolios. ${ }^{18}$

KML entered into a pilot program with the Howard Hughes Medical Institute (HHMI) in which 20 leading professors/researchers are receiving $\$ 1$ million each over the next four years to improve the way undergraduates are taught science. ${ }^{19}$ The HHMI professors are using the KEEP toolkit to document and share their work over the four-year project. $^{20}$

\section{Issues and Challenges of Teaching E-Portfolios}

The effective construction and use of teaching e-portfolios exploits multimedia and the linking capabilities of electronic environments to provide an authentic representation of teaching and learning. The use of video, audio, and graphics, for instance, gives e-portfolio reviewers a clear window into what really happens inside the classroom. Developers of teaching e-portfolios face the following challenges:

- Information overload: Readers can easily become overwhelmed with excessive, disorganized information in the electronic form.

- Technology: Training faculty in how to use technology effectively is challenging.

- Copyright and privacy issues: Providing authentic examples of student work poses legal issues. $^{21}$

- Adoption: Supporters of teaching e-portfolios are seeking effective ways to generate faculty buyin and educate faculty on how to use e-portfolios to showcase their work and share best practices for teaching and learning. ${ }^{22}$ Seldin offered two pieces of advice related to adopting teaching eportfolios. First, teaching e-portfolio adoption is likely to be more successful if it is a grassroots approach rather than a top-down administrative decision. Second, adoption is more successful when the pilot group is diverse; the group's work should be public and shared in open, welldocumented meetings. ${ }^{23}$

\section{Institutional E-Portfolios}

Institutional e-portfolios incorporate student and teaching e-portfolios as well as e-portfolios from a wide range of programs and departments. An institutional e-portfolio would typically present "a focused selection of authentic work, data, and analysis that demonstrates institutional accountability and serves as a vehicle for institution-wide reflection, learning, and improvement." ${ }^{24}$ Material may include

- videotaped interviews,

- photographs,

- audiotaped interviews, 
- quotes in written form, and

- work samples.

Institutional e-portfolios are relatively new. The Urban Universities Portfolio Project (UUPP) was the first formal initiative to explore institutional e-portfolios (http://www.imir.iupui.edu/portfolio/). UUPP was a collaboration among six urban public universities to develop institutional e-portfolio prototypes. $^{25}$

Indiana University-Purdue University Indianapolis (IUPUI) and Portland State University (PSU), both UUPP institutions, are frequently cited for using institutional e-portfolios as in-depth self-study vehicles and as primary-evidence sources for reaccredidation. IUPUI used its institutional e-portfolio to support its successful reaccredidation review by the North Central Association of Colleges and Schools in 2002. PSU is doing the same in 2005 with the Northwest Commission on Colleges and Universities (NWCCU).

The Western Association of Schools and Colleges (WASC) has also begun to encourage institutions to build e-portfolios for accreditation purposes. View examples of e-portfolios from WASC institutions (http://www.wascweb.org/senior/inst resource.htm).

Institutional e-portfolios make the accreditation process more visible because the documentation is published on a Web site. This helps address public accountability concerns regarding educational effectiveness by allowing interested stakeholders (and anyone who has an Internet connection) easy access to what the institution is planning and how it evaluates itself. As one regional accrediting agency official noted:

The vast majority of our evaluators find it useful and powerful to read an electronic report and be able to hyperlink and easily see documents. They can explore and dip in and out [of Web pages]. It is all organized in a much more effective way than printed appendices in a paper report that you have to shuffle through to find things. ${ }^{26}$

Additionally, institutions seeking ways to demonstrate student learning outcomes to their governance boards and the public can find comprehensive and authentic data in student e-portfolios and include it in their institutional e-portfolios, provided that privacy and licensing issues are properly addressed. Data collected from e-portfolios can show how students have made progress collectively rather than individually. ${ }^{27}$ For example, preservice teachers build e-portfolios that have digital artifacts revealing their competencies, based on assignments and teaching practicums that are matched to state or national teaching standards. An institutional research office can aggregate a variety of data from all current and past preservice teacher e-portfolios to reveal how well their institution's teacher candidates meet such standards.

\section{Issues and Challenges of Institutional E-Portfolios}

The issues and challenges of institutional e-portfolios go beyond those for individual e-portfolios.

- Use permission: Using authentic examples of student and faculty work inside an institutional eportfolio raises confidentiality and permission concerns. These issues can be addressed through subject release forms in which students and faculty grant the university permission to use samples of their work. Permanent files of the release forms are then maintained in an electronic database of the participants' names and their contributions. ${ }^{28}$ 
- Complexity and scope of effort: Institutional e-portfolios require significant organizational development and maintenance efforts. ${ }^{29}$ Different organizations, spanning academic affairs and IT, must be involved. And those efforts must be sustained over time and across departmental lines.

- Assembling the right team: Building an effective institutional e-portfolio requires the active participation of institutional research staff, knowledgeable Web developers, graphic designers, and a technical staff with multimedia expertise, as well as strong database construction and maintenance skills. ${ }^{30}$

The complexities of institutional e-portfolios have resulted in a slower adoption rate than for student and teaching e-portfolios; however, the growth of institutional e-portfolios continues to rise as accrediting agencies encourage institutions to provide tangible evidence of educational outcomes.

\section{Lifelong E-Portfolios}

Below are several examples of institutions that offer lifelong e-portfolios.

\section{eFolio Minnesota}

E-portfolios are also moving into the general public through partnerships between local and federal government entities and higher education. The premier example of this is eFolio Minnesota, the nation's first statewide e-portfolio system. It provides every resident of the state of Minnesota the opportunity for a free lifetime e-portfolio of up to $3 \mathrm{MB}$ in storage space (http://www.efoliominnesota.com/).

eFolio Minnesota began in 2001 when the Minnesota State Colleges and Universities system (MnSCU) selected Avenet (http://www.avenet.net/) to develop an e-portfolio system for students, educators, and workers within MnSCU and across the state. The project was a national pilot for the U.S Department of Labor's Career Management Account program, which had an objective of providing U.S. workers with online resources and tools for lifelong learning and career advancement. ${ }^{31}$

Launched in May 2003, by March 2005 eFolio Minnesota had approximately 27,000 registered eFolio users. eFolio is a Web-based system that has been tailored with easy-to-use templates for creating three types of e-portfolios-student, educator, and career. Users can apply restricted, passwordprotected access to parts of their e-portfolios.

A survey of 500 eFolio users showed the tool is being used by a wide range of Minnesotans. Students are using eFolio as they move into the workforce; workers are using eFolio to plan continuing education; and educators are using eFolio to integrate their teaching with their professional work beyond the Academy. ${ }^{32}$

\section{Indiana@Work}

Indiana@Work (http://in.eportfolio.us/Content/Root/Home.aspx), another lifetime, statewide e-portfolio initiative, has yet to fully launch. ${ }^{33}$ It is a joint research and development project between IUPUI's CyberLab and the State of Indiana Departments of Workforce Development and Economic Development. The Epsilen e-portfolio system (http://www.epsilen.com/), owned by IUPUl's CyberLab, provides the underlying architecture for Indiana@Work. 
The goal of Indiana@Work is to establish a statewide networking system that matches job seekers with suitable jobs in the state of Indiana.The Indiana@Work e-portfolio system is currently under development for the State of Indiana Department of Workforce Development. Users create a personal account by simply going to the Indiana@Work Web site and registering. They are then given a unique URL based on their username preference (username.in.eportfolio.us). Like eFolio Minnesota, Indiana@Work is a Web-based system that that uses templates for posting artifacts. Users can also apply restricted, password-protected access to parts of their e-portfolios.

\section{Implementation Issues}

Institutions will want to ask a number of questions as they implement e-portfolio systems, whether they be student, teaching, or institutional. ${ }^{34}$

\section{- Hardware and software}

- How will an e-portfolio system impact other software systems, such as an institution's course management system (CMS), student information system (SIS), and databases?

- How many and what kind of servers will be necessary to hold increasing numbers of e-portfolios? What will be needed to maintain and back up these servers?

- What plugins, file formats, and browsers will be required or supported in any e-portfolio system?

- What technologies will be used to implement an offline, portable portfolio that authors can take with them (XML, content packaging, and so forth)?

\section{- Support and scalability}

- Can the e-portfolio system scale adequately as its usage grows and storage expands?

- Is there an adequate staff to develop, deploy, and maintain the system?

- Will there be an infrastructure in place to properly train students, faculty, and administrators how to use the e-portfolio system?

- Security and privacy

- How will Federal Educational Rights and Privacy Act (FERPA) regulations impact an e-portfolio system?

- What policies need to be in place for governing information access, security, and privacy? How will they be determined and controlled?

- Ownership and intellectual property

- How will an e-portfolio system authenticate that all the work, documentation, and demonstrations were created by the author?

- Who is the real owner of the artifacts in any e-portfolio (author, institution, both)?

- Will fair use laws protect users of others' intellectual property when it is included in an e-portfolio system?

- What can or cannot be included in an e-portfolio?

- Who owns the record? Can it be transferred to another institution?

- Assessment

- What kind of assessments will the e-portfolio system support? What standards (state, special accreditation) will be incorporated into the assessments? 
- How will assessment data be maintained and archived, and for how long?

- How might student assessment be used to assess the programs they participate in? How might this affect the assessment of the institution?

\section{- Adoption}

- What does the administration expect?

- How likely is it that students, faculty, and administrators will accept and use the e-portfolio system?

- Will the system be user-friendly enough for easy adoption?

\section{- Long-term maintenance}

- How will information be maintained over time?

- What policies are needed for transporting or deleting e-portfolios?

- How will long-term storage requirements be managed?

\section{Interoperability and Standards}

The ePortconsortium has helped to clarify the importance of interoperability and standards in the design of e-portfolio software. Standards are the key to ensuring that e-portfolio systems meet user expectations for portability and adaptability. ${ }^{35}$

As students transfer from institution to institution during their educational careers, the ability to transport their e-portfolios into new systems becomes increasingly important. Common standards will help this effort. The IMS Global Learning Consortium (http://www.imsglobal.org/) is making important contributions in this area by establishing an extensive e-portfolio specification to capture information about a learner and the content that the learner wishes to use as evidence of competencies. It also incorporates a rubric specification to help in interpreting competency attainment. ${ }^{36,37}$ The IMS e-portfolio specification will provide a standard for interoperability among systems and support for the transfer of learner products, materials, and records between disparate portfolio systems that adopt it.

\section{E-Portfolio Tool Sets}

Institutions use four basic approaches to develop e-portfolio systems.

- Homegrown: An institution's information technology staff develops a custom system locally. Pros:

- The institution develops exactly what it wants.

- No software licensing fees are involved.

- The institution owns the intellectual property.

Cons:

- Hardware and software development costs can be prohibitive.

- The system may require too much time and energy to design and build.

- High levels of software development and technical expertise are required to build and maintain the system.

- The institution may not be able to retain expert staff long enough to sustain and scale the system.

- Open source: Open source e-portfolio system software or system modules are publicly available at no charge. The Open Source Portfolio Initiative (OSPI) (http:www.theospi.org/), for example, is 
a community of individuals and organizations collaborating on the development of nonproprietary, open source e-portfolio software. The initiative is led by chartered workgroups and a board that represents a wide variety of higher education institutions. About 20 institutions are actively involved in contributing to the OSPI software development process. ${ }^{38}$

Pros:

- There is no charge for open source software.

- Members of the community participate in shaping the development of the software. ${ }^{39}$

- OSPI is designed to work with the Sakai Project (http://www.sakaiproject.org/), a communitysource software development effort to build a "collaboration and learning environment" for higher education. ${ }^{40}$

Cons:

- There are costs associated with technical support and maintenance. ${ }^{41}$

- The possibility of an open source initiative dying out and the community disbanding poses risks related to replacement costs.

- Software development and upgrades may not keep pace with needs.

- Commercial: An institution purchases a system from a vendor, similar to any other application provider, which includes the customary licensing and support fees.

Pros:

- No direct software development cost.

- Technical support is handled by the vendor, allowing campus information technologists to focus their efforts on other projects.

- There are well-developed e-portfolio systems from a variety of vendors. ${ }^{42}$

- A CMS may have a built-in e-portfolio solution, keeping the e-portfolio tool within an integrated environment rather than licensing two different applications. A one-stop CMS/ e-portfolio solution may allow for easier authentication of certified learning competencies. ${ }^{43}$ Cons:

- Licensees must adapt to the vendor's pricing structure, which could increase substantially without adequate notification.

- Customer service and technical support may be poor.

- Common tools: An institution uses common HTML editors, such as Microsoft Front Page or Macromedia Dreamweaver, to support the development of e-portfolios.

Pros:

- More creative e-portfolios are possible because these tools do not lock users into a predefined, structured approach, unlike database- and form-driven e-portfolio systems where users must fill out specific fields and answer questions in order to create their e-portfolios.

- Allows e-portfolio creators to design and enter artifacts in any manner they desire.

- Software cost is low or nonexistent.

Cons:

- Requires students to have Web site authoring skills (for example, an understanding of HTML code) rather than being able to rely on a template-driven approach where students fill out forms to create preformatted Web pages. 


\section{E-Portfolio Examples}

What follows is only a small sample of the wide variety of e-portfolio systems and models available, grouped by type of system.

\section{Homegrown System}

Three examples of homegrown systems are detailed below.

\section{University of Denver (DU)}

The DU Portfolio Community (DUPC) system (https://portfolio.du.edu/pc/index) supports individual, course, and community portfolios, as well as curriculum assessment. ${ }^{44}$ DUPC is a homegrown e-portfolio system that began during the late 90 s through a $\$ 230,000$ grant earmarked for students and faculty in the School of Communication. However, before any concrete decisions were made about how to develop the system, interest in it quickly spread across DU, which led to the formation of an e-portfolio committee comprised of students, faculty, and staff representative of the entire campus community.

After four years of internal development, DUPC launched its first e-portfolio system in September 2002. It is considered a mature, mission-critical system housed on servers maintained by DU's technology services department. By 2004, students, alumni, and staff had created 6,400 e-portfolios (DU had a total combined undergraduate and graduate student population of about 10,000 in 2005); in addition, the system included 540 faculty e-portfolios.

DUPC features, functions, and methods of operation highlight key e-portfolio issues and challenges. The e-portfolio system runs on a Sun Microsystems platform with an Oracle back-end enterprise database and is housed on three servers. More than 300 screens make up the application. It is fully integrated with DU's SCT Banner enterprise-wide administrative computing environment.

All users are first authenticated by their roles at the university (administrator, faculty, student, alumni, and so on). Students, faculty, staff, and alumni have equal access to the system. The system allows users to set access permissions to the objects they put into their e-portfolios. All e-portfolios are accessible online through an easy-to-remember URL (http://portfolios.edu/username). Campus groups/communities can create special e-portfolios. For example, DUPC has a growing list of communities using e-portfolios, including a new faculty community; a Graduate Student Association Council community; a "Making of a Scientist" community for high school students interested in learning about the relationship between mathematics, computer science, and chemistry; and many other communities related to courses, departments, organizations, and like-minded groups.

The system includes an important assessment management component that houses a large rubric library available to everyone on the system that was created by faculty in collaboration with DU's Office of Assessment.

Users can post whatever they want on their e-portfolio Web sites, provided they are within the university's acceptable use policies for computer and network systems, which includes copyright and intellectual property rules and regulations. If something is posted that runs counter to the university's use policies, it is removed.

DU has addressed many long-term maintenance and support issues. There are no storage quotas; the average size of an e-portfolio is $2-5 \mathrm{MB}$, but some users have e-portfolios greater than $200 \mathrm{MB}$. The system operates under a continuous improvement cycle in which new releases are created 
based on student and faculty feedback every quarter. There is no export or transportability model, as users receive their own URL and can use DUPC for life at no cost. The system automatically sends e-mail to users who haven't shown any activity for six months asking if they want to remain on the system. The e-portfolio help desk gets only 15 to 30 calls per quarter. ${ }^{45}$

\section{University of Washington (UW)}

The UW Catalyst Portfolio tool (http://catalyst.washington.edu/tools/ppp.html), developed by UW's Catalyst Group, is another homegrown Web-based system with a large user base. ${ }^{46}$ It was created for students to collect, reflect, and present artifacts of their work and learning experiences online.

The Catalyst Group began developing this e-portfolio system in December 2001, after a request from an "action-plan group" of university administrators, including representatives from academic advising and career planning offices. Their goal was to build a tool that could help UW students build e-portfolios that could represent their entire educational experience from freshman year through graduation in an organized, integrated, and progressive fashion.

The Catalyst Portfolio tool was launched in September 2002, with an incoming freshman class participating in UW's freshman interest group program. An appropriation from UW's student technology fee committee covered a good portion of the initial development costs $(\$ 92,100)$ of the tool. In 2002-03, the committee allocated another $\$ 32,000$ for added storage space. ${ }^{47}$ Since 2002 , approximately 80 percent of all incoming freshman have been introduced to the tool. As of early 2005 , 15,000 students and 1,200 instructors, advisors, or mentors had created e-portfolios. ${ }^{48}$

The Catalyst Portfolio tool has been called "a big dumb smart tool" because it is basically a file manager built around templates that allow users without HTML skills to easily create and publish Web pages. It also allows users with HTML skills to add HTML formatting options for inclusion in their eportfolio designs. Unlike e-portfolio tools that involve prescribed artifacts for specific course or program requirements, the UW e-portfolio system allows users to create anything they want within the university's copyright and intellectual property policies. ${ }^{49}$

The tool is promoted to the campus community as a means to collect, annotate, arrange, and display a variety of digital artifacts that illustrate accomplishments. Users are encouraged to create online portfolios for a wide variety of reasons, including archiving learning experiences and specific course work or collecting and displaying artifacts for graduate school admission or job applications.

After graduation, all UW students are allowed up to $500 \mathrm{MB}$ of storage space for their e-portfolios; however, as of early 2005, a solid policy regarding access after graduation was still under development. Thus far, no UW alumni have been denied access. Additionally, users can download their e-portfolio and transfer it to another Web server. ${ }^{50}$

In addition, the Catalyst Group developed a Catalyst Portfolio Project Builder companion tool (http://catalyst.washington.edu/tools/portfolio.html) for teachers and career or academic advisors to help guide students through the e-portfolio building process. As students are invited to participate in portfolio projects, the tool asks questions that help them select and present the best examples of their learning experiences. For example, a teacher might use the tool to collaborate with a student in a way that facilitates reflection during the e-portfolio building process and represents progress toward a better understanding of the student's goals and aspirations. ${ }^{51}$ 
University of Nebraska at Omaha (UNO)

UNO has implemented an e-portfolio system for its undergraduate College of Education preservice teacher candidates (http://portfolio.unomaha.edu/). UNO's system is a homegrown, Web-based, database-driven tool designed to systematically demonstrate the growth of teacher candidates. It began with several faculty members' involvement in a Preparing Tomorrow's Teachers to Use Technology (PT3) grant. In the fall of 2002, an E-CORE team comprised of technology support staff, the PT3 coordinator, and five College of Education department chairs was established to develop an e-portfolio system that could

- demonstrate the growth of teacher candidates;

- communicate the scope of the College of Education program and its alignment to Interstate New Teacher Assessment and Support Consortium (INTASC) principles;

- demonstrate program review and evaluation of the College of Education for National Council for Accreditation of Teacher Education (NCATE) accreditation purposes;

- create student and teacher portfolios for career advancement purposes; and

- provide a model for the UNO Vice Chancellor for Academic and Student Affairs Office to develop a campus-wide e-portfolio initiative. ${ }^{52}$

As of early 2005, 1,500 College of Education students had e-portfolios in which their artifacts were linked to INTASC principles. UNO's College of Education is developing a "professional" e-portfolio for its graduates (a portfolio for $\mathrm{K}-12$ professionals). A consortium of human resource departments at six local school districts outlined the essential components of a professional e-portfolio that would best serve the districts' teacher hiring processes:

- a résumé;

- letters of recommendation;

- a list of references;

- a teaching philosophy statement from the beginning and end of a student-teacher's education;

- evidence of teaching, including a lesson package with objectives, procedures, standards, and assessments, as well as a video of the student-teacher teaching the lesson; and

- artifacts that demonstrate a student teacher's capabilities.

The College of Education is working to enable other programs to customize the e-portfolio system's architecture to their specific purposes. In addition, a different common-tools e-portfolio initiative is taking shape in general education courses such as English, which may eventually be integrated with the College of Education system. An overriding goal for these initiatives is to create a coordinated series of e-portfolios so that data from faculty and student e-portfolios can be incorporated in an institutional e-portfolio. ${ }^{53}$

\section{Open Source System}

Two examples of open source systems are detailed below.

Virginia Tech (VT)

The VT Electronic Portfolios pilot (VTeP) (https://eportfolio.vt.edu/) dates to the summer of 2002 when a core curriculum committee considered the design and enactment of general and integrative studies. 
The committee proposed exploring means for students to capture, maintain, and reflect on the work they do, both across the curriculum and over their entire VT academic career. ${ }^{54}$

The committee's proposal led to the establishment of an e-portfolio task force during the fall/winter of 2002-03. The task force included representatives from the Educational Technologies Department, the Center for Excellence in Undergraduate Teaching, and faculty and students representing a broad range of disciplines. By the spring of 2003, after reviewing commercial e-portfolio products, the task force decided that VTeP should join OSPI.

The development process of VTeP has been characterized as a "pretty major undertaking" that required "a fair amount of modification" to the OSPI code. The fall 2002 pilot began with 12 faculty in such courses as communications, English, agricultural economics, engineering, and professional writing who incorporated e-portfolios into their course syllabi, resulting in 270 student-created e-portfolios.

Since this first phase of VTeP, a communication campaign initiated by the task force has increased interest from other departments and programs. E-portfolios have also been introduced to Virginia Tech faculty through its Faculty Development Institute, which is a critical component of Virginia Tech's strategic, university-level Instructional Development Initiative.

The College of Engineering has shown particular interest in incorporating e-portfolios as a measure of program assessment for its students, and e-portfolios have started to move from the course level to the program level. Where VTeP had 750 student e-portfolios at the close of spring 2004, the number jumped to approximately 2,500 students the following fall semester (with 1,400 coming from the College of Engineering). ${ }^{55}$

\section{University of Texas at San Antonio (UTSA)}

Like UNO, UTSA began its e-portfolio initiative (http://eportfolio.utsa.edu/) through a PT3 grant in its College of Education. UTSA adopted the OSPI platform. The e-portfolio initiative targeted UTSA's teacher education program. Preservice teacher-preparation faculty saw e-portfolios as a method for assessing student learning over time, tool for reflection, and way to support their own adoption of technology. By spring 2004, the entire special-education student population and all preservice teachers were using the system (about 400 students and faculty). This effort, however, has taken about three years and is still in a developmental phase.

Those working on the project have developed a number of portfolio system hierarchies—one for students and two for faculty. Hierarchies are contextual aids that provide the framework for including specific information in e-portfolios. The student hierarchy, for example, is designed to help preservice teachers see the connections between their educational pathway and the mission of the college, the conceptual framework for their teacher training, their overall education, and State Board of Education standards. The faculty hierarchies include a "professional résumé" with a long list of elements that can be used for annual review and a "course portfolio" that allows faculty to more easily share their courses with adjuncts.

In the meantime, UTSA is adapting as more users join the system and more artifacts are deposited in their e-portfolios. One challenge is that many of UTSA's preservice teachers are uploading relatively large video files to only one e-portfolio server; work is under way to provide more server space. Another issue is that groups such as career services and a freshman initiative are becoming interested in the system. A committee is developing strategies to include other departments in the e-portfolio system. ${ }^{56}$ 


\section{Commercial System}

An example of a commercial system is detailed below.

\section{Western Governors University (WGU)}

WGU uses a commercial e-portfolio system-Taskstream -in its rapidly growing Teachers College. It has yet to be widely adopted by other WGU divisions. As of the winter semester 2005, WGU had 2,130 students enrolled in its Teachers College and was enrolling an average of 200 new students each month. Students who plan to become certified teachers must create an e-portfolio as part of "Demonstration Teaching" component. Their e-portfolios include representations of the results of their interactions, recommendations from colleagues and administrators, a variety of resume-like elements, and the materials student-teachers need to document their experiences and competencies.

Students pay a small fee (less than $\$ 50$ included in their tuition) for using Taskstream. They learn how to use the tool through an online training program that includes voice and video components. There is a full-time trainer on the WGU staff who provides support as students learn how to build their e-portfolios. The e-portfolios are housed on Taskstream servers through an application programming interface (API) arrangement that ties the e-portfolios to WGU's SCT Banner system. When students graduate, they pay a fee to Taskstream to retain their e-portfolios.

Currently WGU's business department is investigating e-portfolios, and institutional-level discussions are occurring regarding the use of e-portfolios for internal management purposes. ${ }^{57}$

\section{Common Tools System}

An example of a common tools system is detailed below.

\section{St. Olaf College}

St. Olaf College has a common-tools approach to their e-portfolio environment, called Web portfolios (http://www.stolaf.edu/depts/cis/web portfolios.htm). Web portfolios are being used effectively inside an individual majors program that is managed by St. Olaf's Center for Integrative Studies (CIS). The individual majors program allows a student to devise a curriculum, with CIS approval, on any subject that permits coherent, in-depth study using college resources without duplicating an existing program.

The development of Web portfolios at St. Olaf College started in 1999, based on a Mellon Foundation grant to support new uses of technology. The process began with a group of faculty that examined the rationale and pedagogy of Web portfolios. The e-portfolio environment was launched in 2001 as a requirement for all individual majors. Rather than being driven by program assessment, career development, certification requirements, or accreditation purposes, the college's decision to adopt Web portfolios was motivated entirely by considerations of pedagogy and student intellectual development. ${ }^{58}$

Created with Macromedia Dreamweaver, most of the student e-portfolios are collections of a student's work that "illustrate the unfolding or meaning of his or her academic career," with "hyperlinks to demonstrate how the student understands relationships among many individual achievements, including links to work of peers, and to work presented at external sites." ${ }^{.59}$

The St. Olaf student e-portfolios reveal a wide range of styles and individual differences, with some students displaying more skills at Web-site building than others. Some students display a "sophisticated self-awareness" through the creation of content that shows how their learning 
experiences have been integrated into their specific majors. Other students "simply jumble a lot of work products into a folder and index them...." While some students grasp the usefulness of the Web to present their ideas, others don't and find the requirement "burdensome."60

While these e-portfolios are not graded, academic advisors in the individual majors program evaluate them and offer guidance, support, and mentoring in their development. After the student graduates, the e-portfolio remains on the St. Olaf server for one year. All of the student e-portfolios for any given individual majors senior class-typically about 15 students-are burned onto a CD and given to students upon graduation.

\section{Conclusion}

Those who have adopted e-portfolios claim they are the biggest educational technology development since the adoption of course management systems. Although promising, e-portfolios are not yet a mainstream higher education technology.

E-portfolios have become a primary way for students, faculty, and staff to document skill sets and reflect on learning, accomplishments, and career goals. Institutions are beginning to realize that eportfolios are a viable tool that strengthens self-study and accreditation processes. The result is that an increasing number of institutions recognize that e-portfolios are a technology with enterprise-level implications. As e-portfolio applications grow, they need to be integrated across campus systems.

E-portfolios show promise across all types of institutions, disciplines, and applications. We encourage you to explore the examples provided in this report. We hope you will send us information on how you are using e-portfolios to advance learning and learner success (eli@educause.edu).

\section{Endnotes}

1. E-portfolios are also referred to as Webfolios and digital portfolios.

2. G. Greenberg, "The Digital Convergence: Extending the Portfolios Model," EDUCAUSE Review, vol. 39, no. 4 (July/August 2004), pp. 28-36, <http://www.educause.edu/apps/er/erm04/erm0441.asp>.

3. University of British Columbia Office of Learning Technology, <http://www.olt.ubc.ca/>.

4. "Update on Electronic Portfolios," Educational Pathways, October 2003 (interview with D. Cambridge).

5. D. Cambridge, personal communication, February 2005.

6. S. Acker, "Overcoming Obstacles to Authentic E-Portfolio Assessment," Campus Technology Newsletter: Technology-Enabled Teaching/eLearning Dialogue, March 2005, <http://www.campus-technology.com/news article.asp?id=10788\&typeid=155>.

7. K. B. Yancey, "Digitized Student Portfolios," in Electronic Portfolios: Emerging Practices in Student, Faculty, and Institutional Learning, B. L. Cambridge, S. Kahn, D. P. Tompkins, and K.B. Yancey, eds. (Washington, D.C.: AAHE, 2001, pp. 15-30).

8. B. L. Cambridge, personal communication, February 2005.

9. T. Lewis, personal communication, February 2005.

10. Ibid.

11. American Association for Higher Education (AAHE), "CO2 Electronic Portfolio Use: Learning Principles and Effects," 2003 Synthesizer Reports for Communities of Practice, Role, and Identity, Community Leader Darren Cambridge. 
12. H. Barrett, "Electronic Portfolios as Digital Stories of Deep Learning" (August 2004), $<$ http://electronicportfolios.org/digistory/epstory.html>.

13. AAHE, op. cit.

14. G. Siemens, "E-Portfolios," elearnspace, everything elearning (December 16, 2004), $<$ http://www.elearnspace.org/Articles/eportfolios.htm>.

15. P. Seldin, personal communication, February 2005.

16. B. Thomson, "UBC Teaching e-portfolio/FAQ," UBC Wiki (April 13, 2005), $<$ http://careo.elearning.ubc.ca/cgi-bin/wiki.pl?UBC Teaching EPortfolio/FAQ>.

17. See the UBC teaching e-portfolio Wiki for links to teaching e-portfolio examples, $<$ http://careo.elearning.ubc.ca/cgi-bin/wiki.pl?UBC Teaching EPortfolio>.

18. T. liyoshi, personal communication, February 2005.

19. Howard Hughes Medical Institute, "Howard Hughes Medical Institute's Million-Dollar Professors" (September 18, 2002), <http://www.hhmi.org/news/091802.html>

20. T. liyoshi, op. cit.

21. S. Kahn, "Making Good Work Public Through Electronic Teaching Portfolios," in The Teaching Portfolio: A Practical Guide to Improved Performance and Promotion/Tenure Decisions, 3rd ed., P. Seldin, ed. (Bolton, Mass.: Anker Publishing, Inc., 2004), pp. 36-50.

22. AAHE, op. cit.

23. P. Seldin, op. cit.

24. S. Kahn, "Linking Learning, Improvement and Accountability: An Introduction to Electronic Institutional Portfolios," in Electronic Portfolios: Emerging Practices in Student, Faculty, and Institutional Learning, B. L. Cambridge et al., eds. (Washington, D.C.: AAHE, 2001), pp. 135-158.

25. For more information about UUPP and institutional e-portfolios, see the Institutional Portfolios section in Electronic Portfolios: Emerging Practices in Student, Faculty, and Institutional Learning, B. L. Cambridge et al., eds. (Washington, D.C.: AAHE, 2001), pp. 135-217.

26. E. Griego, personal communication, February 2005.

27. B. L. Cambridge, op. cit.

28. K. A. Ketcheson, "Portland State University's Electronic Institutional Portfolio: Strategy, Planning, and Assessment" in Electronic Portfolios: Emerging Practices in Student, Faculty, and Institutional Learning, B. L. Cambridge et al., eds. (Washington, D.C.: AAHE, 2001), p. 185.

29. E. Griego, op. cit.

30. S. Kahn, op. cit.

31. Avenet, "Minnesota State College \& Universities System Selects Avenet to Build Statewide Electronic Portfolio Project," Avenet press release (August 2001), <http://www.avenetefolio.com/index.asp?Type=B PR\&SEC=\{6D124B20-C790-4A0A-8FBC-0A7927A450BC\}>.

32. D. Cambridge, op. cit.

33. A. Jafari, personal communication, February 2005.

34. Implementation issues were adapted from ePortConsortium, "Electronic Portfolio White Paper," A. Jafari and G. Greenburg, eds. (November 2003), <http://www.eportconsortium.org/Content/Root/whitePaper.aspx>.

35. Ibid 
36. The IMS Global Learning Consortium (http://www.imsglobal.org/) is a nonprofit organization with more than 50 contributing members and affiliates from varied sectors of the global e-learning community. IMS develops and promotes the adoption of open technical specifications for interoperable learning technology. Several IMS specifications have become worldwide de facto standards for delivering learning products and services.

37. S. Griffin, e-mail correspondence, March 3, 2005. IMS is releasing the official internationally developed e-portfolio specification in 2005.

38. C. Coppola, personal communication, February 2005. (Note: Coppola said that the latest version of OSPI is a complete architectural redesign that more easily accepts add-on components from other developing partners.)

39. B. Wheeler, "The Open Source Parade," EDUCAUSE Review, vol. 39, no. 5 (September/October 2004), pp. 68-69, <http://www.educause.edu/pub/er/erm04/erm0458.asp>.

40. The Sakai Project (http://www.sakaiproject.org/) is funded by the University of Michigan, Indiana University, MIT, Stanford, the uPortal Consortium, and the Open Knowledge Initiative (OKI), with the support of the Andrew W. Mellon Foundation.

41. For OSPI, the r•smart group (http://www.rsmart.com/), which is a founding OSPI member, provides fee-based support for institutions that have adopted OSPI software.

42. A short list of commercial e-portfolio providers includes Chalk and Wire (http://www.chalkandwire.com/); ePortaro (http://www.eportaro.com/); FolioTeck (http://www.foliotek.com/); LiveText (http://college.livetext.com/); Nuventive's iWebfolio, in alliance with SCT (http://www.nuventive.com/iwebfolio.htm); Taskstream (http://www.taskstream.com/); and TrueOutcomes (http://www.trueoutcomes.com/).

43. A. Jafari, personal communication, February 2005.

44. Anyone can register as a guest at DUPUC and participate in discussion forums, browse portfolios, subscribe to communities, and search the portfolio community.

45. J. Gilbert, P. Ross, and J. Rutenbeck, "Electronic Portfolios in Higher Education: Where Are We and Where Are We Going?" presentation at the EDUCAUSE Annual Conference, Denver, Colo., October 20, 2004, <http://www.educause.edu/E04/Program/1663?PRODUCT CODE=E04/SESS039>.

46. The Catalyst Group is a division of UW's Educational Partnerships and Learning Technologies (EPLT) Department, $<$ http://catalyst.washington.edu/home.html>.

47. T. Lewis, op. cit.

48. Ibid.

49. G. Lorenzo, “UW Home-Grows Impressive E-Portfolio Tools," Educational Pathways, May 15, 2003, p. 7.

50. T. Lewis, op. cit.

51. For an example of a fictitious reflection-oriented portfolio using the Catalyst Portfolio Tool, see $<$ http://portfolio.washington.edu/ctltstaf/reflection-portfolio-2004/index.html>.

52. S. Wetig, P. Clark, and N. Topp, "University of Nebraska at Omaha Digital Portfolio," Society for Information Technology and Teacher Education International Conference, vol. 2004, issue 1 (2004), pp. 3658-3663.

53. N. Topp, personal communication, February 2005.

54. Virginia Tech Core Curriculum Committee, "Reviewing General and Integrative Education at Virginia Tech" (January 2003), <http://www.ceut.vt.edu/pdf2/Report Jan31 03 final.PDF>.

55. J. Moore, personal communication, February 2005.

56. P. McGee, personal communication, February 2005.

57. J. Schnitz, personal communication, February 2005. 
58. D. Booth, personal communication, February 2005.

59. D. Booth, "Taking the Web in Web Portfolios Seriously," presentation to a roundtable at the AAC\&U Annual Meeting, January 2002.

60. D. Booth, op. cit. 


\section{Appendix 1: Examples of E-Portfolios}

Student e-portfolio: Academic oriented

Tool: Common tools approach, created with an HTML editor

Author: Jamie L. Lepore, St. Olaf College, Individual Majors Program

URL: http://www.stolaf.edu/depts/cis/wp/lepore/index2.html

Description: Lepore's e-portfolio shows a description of her major and how she completed her senior project, including her final paper and a PowerPoint presentation that she gave to the Center for Integrative Studies before graduating in 2004.

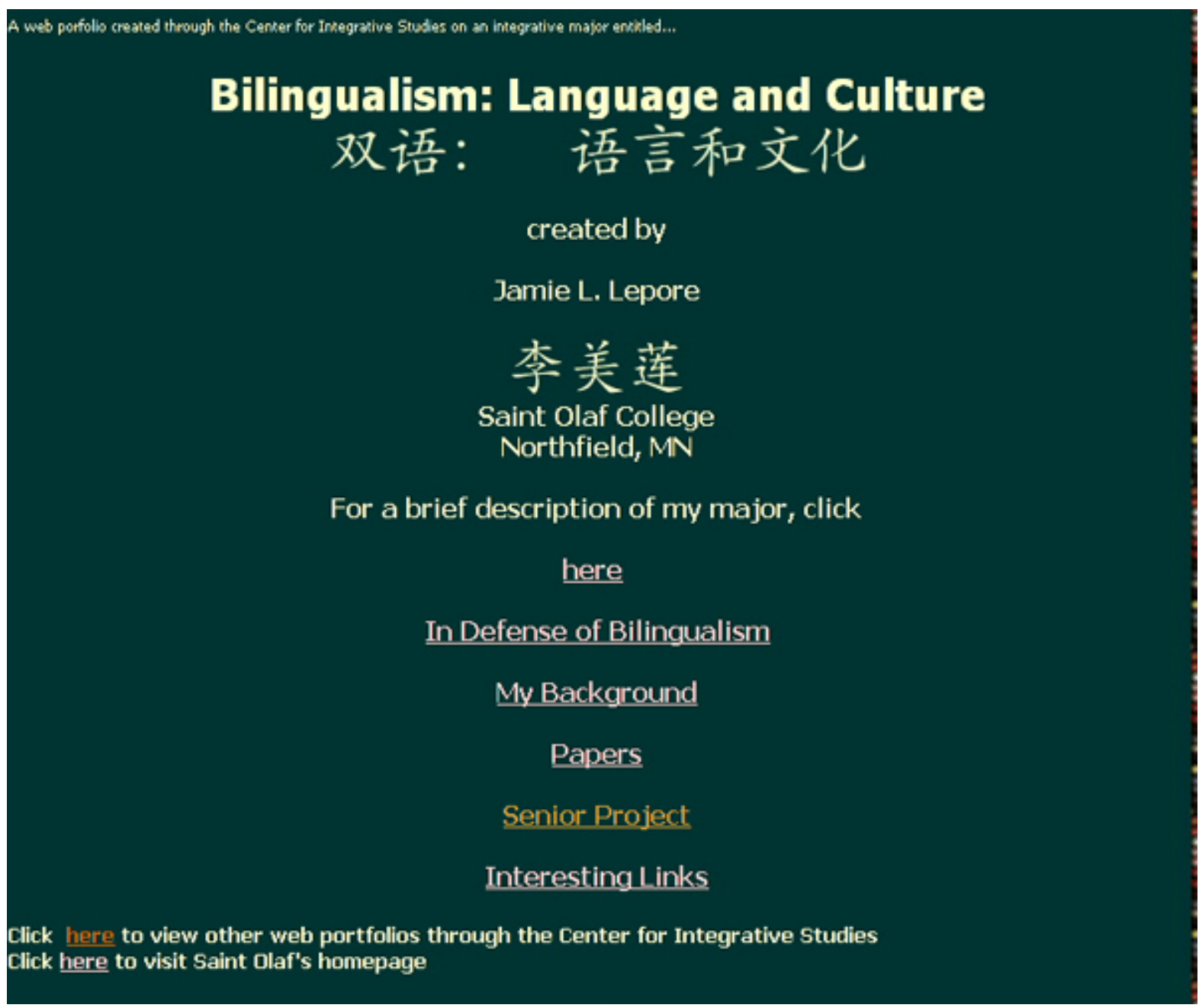


Student e-portfolio: Academic and career oriented

Tool: Catalyst Portfolio tool

Author: Rochelle Martin, University of Washington

URL: http://portfolio.washington.edu/shell32/rochelle-martin---soprano/

Description: Martin's e-portfolio reveals her many accomplishments as a student working toward her bachelor's in music in vocal performance and as an opera singer. It includes photos and audio files of her performances while an undergraduate student.

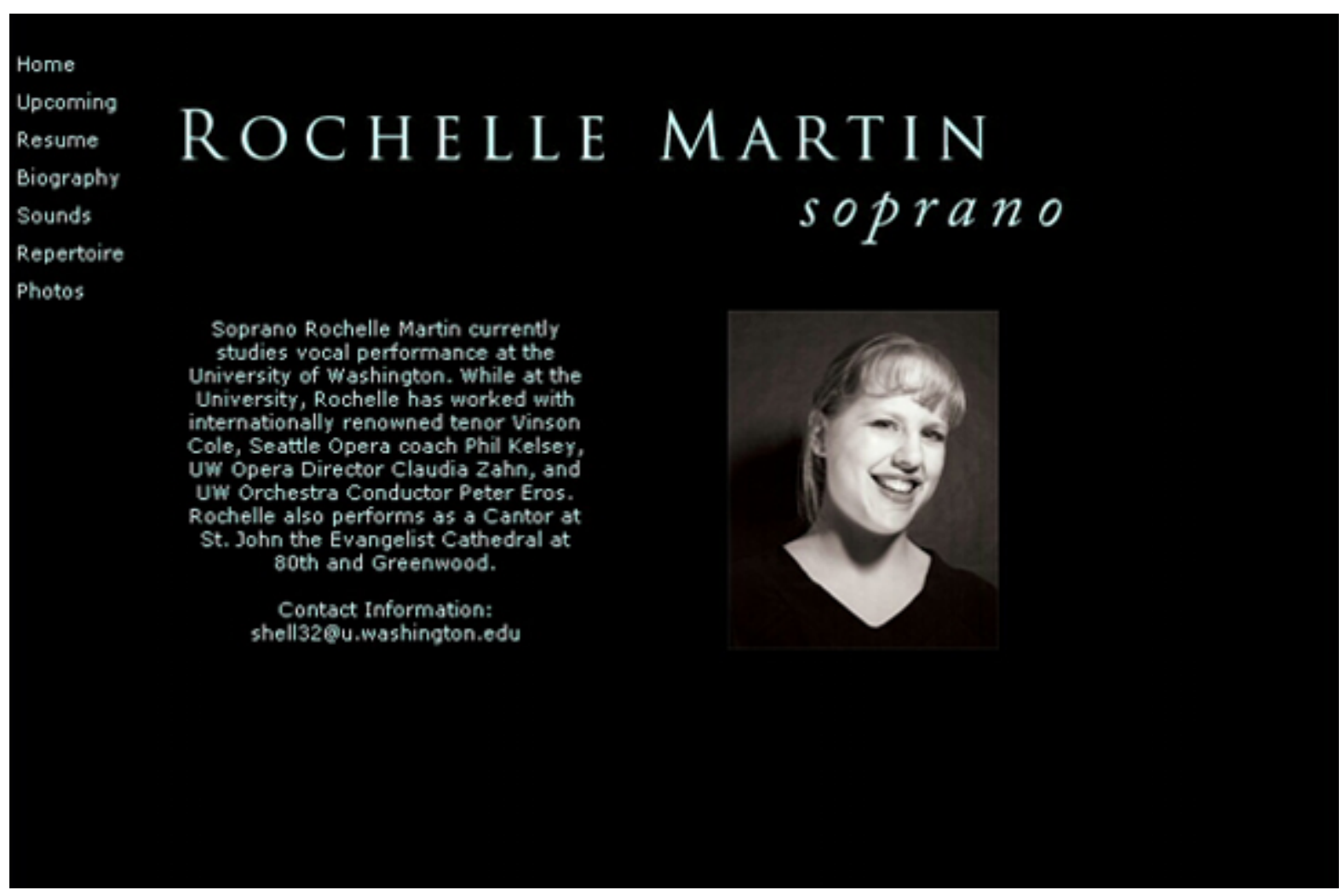




\section{Teaching e-portfolio: Career oriented}

Tool: iWebFolio

Author: Bjorn Thomson, University of British Columbia

URL: http://www.bjornthomson.ca/index.htm

Description: Thomson's teaching e-portfolio covers many aspects of his academic career. It lists the courses he has taught, the workshops he has led or cofacilitated, links to student evaluations of his courses, professional development workshops and conferences he has participated in, and more.

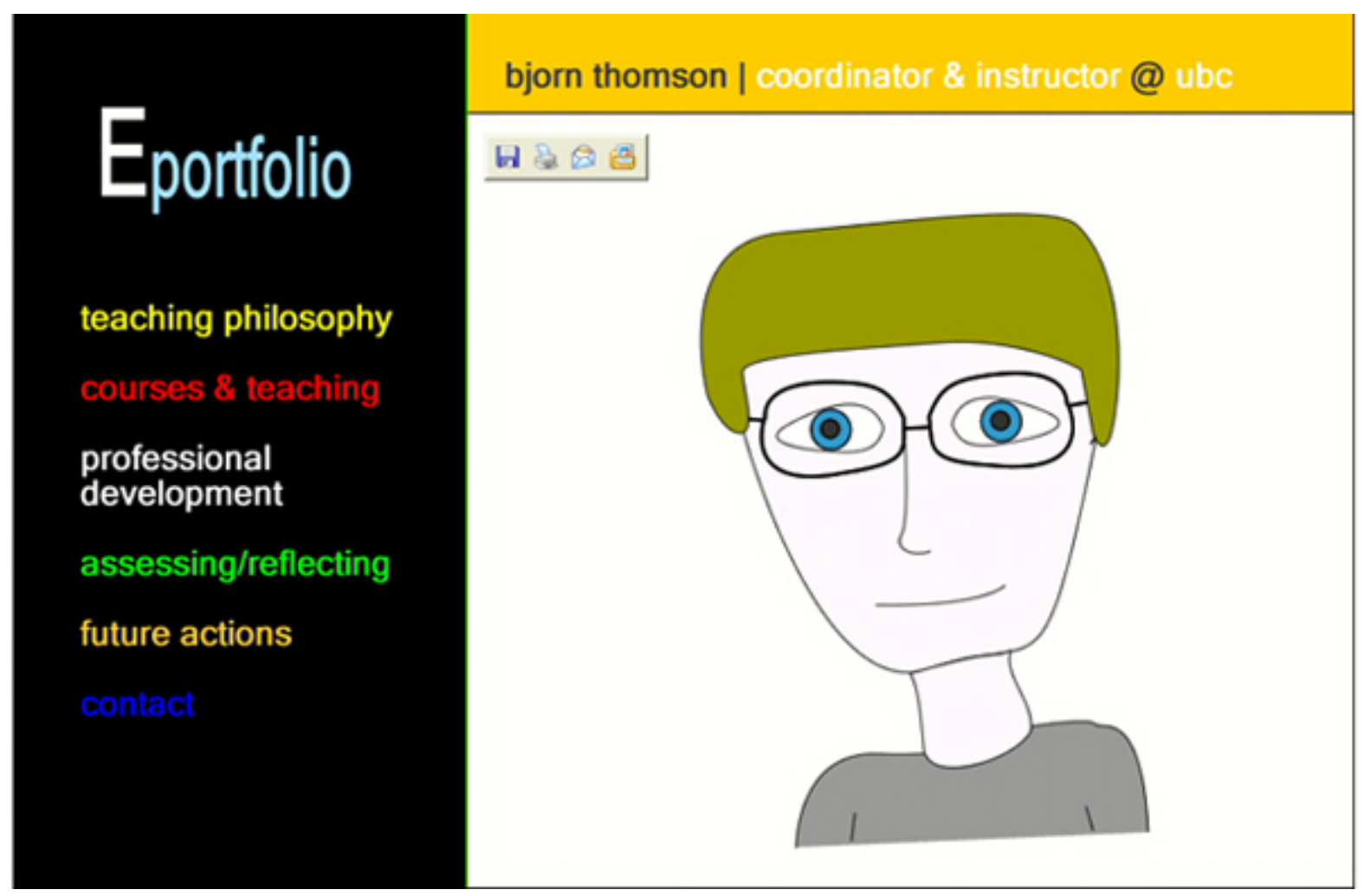


Teaching e-portfolio: Academic oriented

Tool: KEEP toolkit

Author: Curtis Bennett, Michigan State University

URL: http://gallery.carnegiefoundation.org/cbennett/

Description: Bennett's teaching e-portfolio is based on a course he taught and is meant to

- "capture a possible vision of what such a capstone course for secondary education majors can do";

- aid his memory by helping him remember key issues whenever he teaches the course; and

- investigate student learning and learn "how certain portions of the capstone class affected student learning."

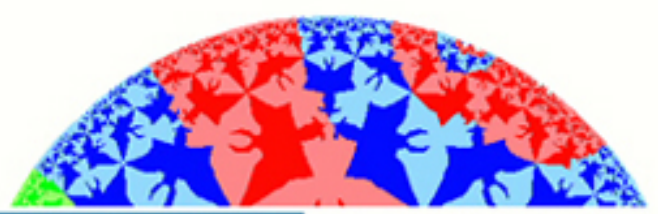

Central Inquiry :

\begin{tabular}{|c|c|}
\hline $\begin{array}{l}\text { Course } \\
\text { overview }\end{array}$ & $\begin{array}{l}\text { Desired } \\
\text { Course } \\
\text { Qutcomes } \\
\text { and } \\
\text { Assessment } \\
\text { of Outcomes }\end{array}$ \\
\hline $\begin{array}{l}\text { Changes in } \\
\text { the Course } \\
\text { Wrought by } \\
\text { the Project }\end{array}$ & $\begin{array}{l}\text { A surprising } \\
\text { development } \\
\text { on student } \\
\text { conversations }\end{array}$ \\
\hline $\begin{array}{l}\text { Reflections } \\
\frac{\text { on The }}{\text { Course }}\end{array}$ & $\frac{\text { Concluding }}{\text { Remarks }}$ \\
\hline$\frac{\frac{\text { Portfollo }}{\text { Companion }}}{\frac{\text { Printout }}{\text { (PDF) }}}$ & References \\
\hline
\end{tabular}

Supporting

Documents:

History of the Course
Advanced Mathematics for Secondary

Teachers: Course Portfolio

For the Fall 2000 class taught at Michigan State

University

Curtis Bennett

I designed this portfolio for multiple purposes and viewers. Your interests should determine how you navigate the portfolio. I have styled it after an artist's portfolio: the main portion consists of ten "snapshots," each of which might be examined for minutes or hours. These snapshots are also linked so that you need never return to this page. As the choices at this stage might seem a bit overwhelming, there are links to five teaching "problems" or questions that I have addressed in this portfolio. Chasing each of these links leads to a page with frames that will provide you with one path to follow through the portfolio. My suggestion, however, would be to start with one of these paths and then follow your interests.

\begin{tabular}{|c|c|c|c|c|c|c|c|c|c|}
\hline \multicolumn{10}{|c|}{ Snapshots/ Artifacts of My Teaching } \\
\hline $\begin{array}{l}\text { The first two } \\
\text { homemorks: } \\
\text { Setting the } \\
\text { stage. }\end{array}$ & $\begin{array}{l}\text { Pesearch } \\
\text { Projects: } \\
\text { The games } \\
\text { plan. }\end{array}$ & $\begin{array}{l}\text { The } \\
\text { Midterm: } \\
\text { A } \\
\text { halferax } \\
\text { peins. }\end{array}$ & $\begin{array}{l}\text { The dax } \\
\text { the } \\
\text { teacher } \\
\text { bid in } \\
\text { the } \\
\text { comer. }\end{array}$ & $\begin{array}{l}\text { Homemork } \\
\text { on } \\
\text { Algebras } \\
\text { sumbers. }\end{array}$ & $\begin{array}{l}\text { A group } \\
\text { thast } \\
\text { didn's } \\
\text { wotk: } \\
\text { The } \\
\text { fabre. }\end{array}$ & $\begin{array}{l}\text { A student's } \\
\text { joumey to } \\
\text { mathematics. }\end{array}$ & $\begin{array}{l}\text { Dedekind } \\
\text { Cuts: The } \\
\text { Crescende }\end{array}$ & $\begin{array}{l}\text { The } \\
\text { student } \\
\text { Project } \\
\text { Papers. }\end{array}$ & Ihe \\
\hline
\end{tabular}

I see my portfolio as a combination of three purposes of course portfolios outlined by Pat Hutchings (1998):

- A vision of the possible: I designed the mathematics capstone course 


\section{Institutional e-portfolio: California State University, Sacramento (CSUS)}

Tool: Macromedia Dreamweaver

URL: http://www.csus.edu/portfolio/index.htm

Description: This institutional e-portfolio presents a variety of departmental and program plans, self studies, and digital artifacts that represent learning outcomes and effective educational practices.

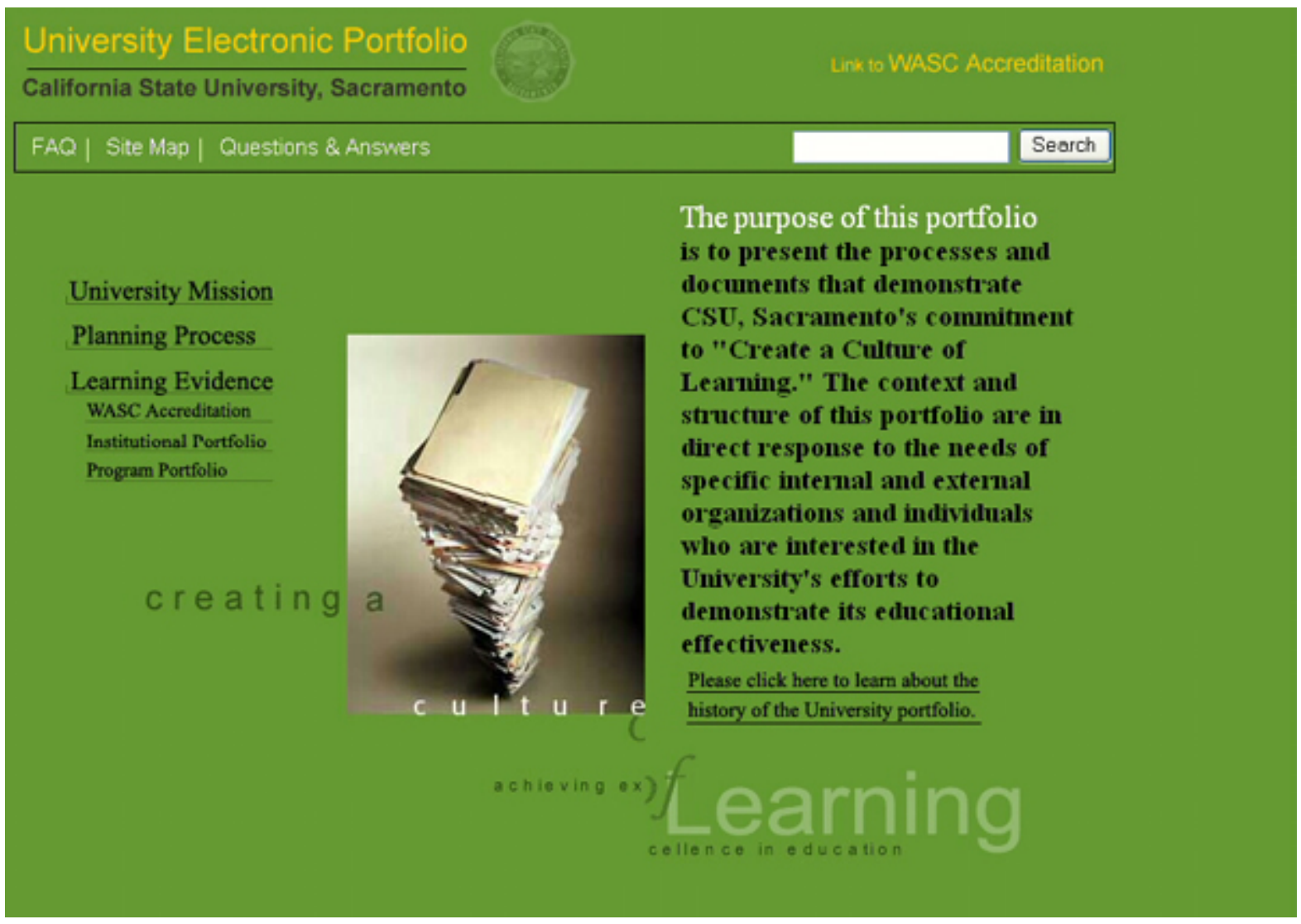




\section{Institutional e-portfolio: Portland State University (PSU)}

Tool: Zope (open source content management tool)

URL: http://portfolio.pdx.edu/

Description: PSU's institutional e-portfolio is a Web site for "self-evaluation, reflection, and planning" that includes discussion boards for PSU faculty and staff to provide their thoughts on campus issues while viewing e-portfolio pages. The Office of Institutional Research maintains a database of submissions and periodically provides summaries of the discussions on the e-portfolio Web site.

\section{$\operatorname{ten} \mid$ no gtx $\mid$ atx \\ PORTLAND STATE UNIVERSITY PORTFOLIO}

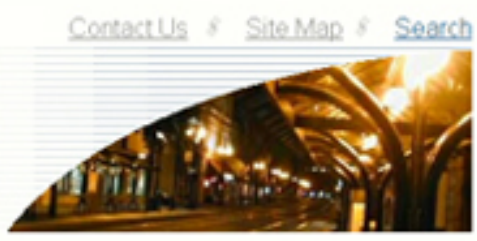

\section{The Portiolio \& Pontolio Tour \& Porttolio FAQ \& Portiolio into is Discussion Boards}

\section{( ENTER THE PORTFOLIO}

Our website for self-evaluation, reflection, and planning

\section{( PORTFOLIO TOUR}

Tours of specific topics for faculty, students and community members

\section{( PORTFOLIO FAQ's}

Frequenty Asked Questions about PSU's Portfolio

\section{( PORTFOLIO INFO}

About The Porttolio Project, documentation, source code, etc

\section{President's Vision}

My vision is of a university so thoroughly engaged with its

community... that people throughout

the region refer to it as 'our university':"

the ragion the Prasidentls Page?

PSU President. Danial O. Bernstine
Accreditation Self-Study

PSU's institutional pontolio will stme as the self-study document for is resfirmation of accredtation in 2005 


\section{Appendix 2: International E-Portfolio Efforts}

A robust e-portfolio movement exists outside the United States, such as the European Institute for ELearning (EIfEL). ElfEL has launched Europortfolio, a consortium whose objective is that every European citizen will have an e-portfolio by 2010 (http://www.eife-l.org/eifel). There's also the European Portfolio Initiatives Coordination Committee (EPICC), a project similar to ElfEL, which is an EPICC partner (http://www.epiccproject.info). Learning Innovations Forum d'Innovation d'Apprentissage (LIFIA) in British Columbia, Canada, is studying e-portfolios (http://www.lifia.ca/en). Finally, the SURF Foundation in the Netherlands supports a special interest group related to e-portfolios, called NL-Portfolio (http://e-learning.surf.nl/portfolio).

\section{Appendix 3: Interviewees}

The following individuals were interviewed for this report.

Melissa Anderson, Senior Pedagogical Advisor, Blackboard Inc.

Helen Barrett, Assistant Professor, Educational Technology, School of Education, University of Alaska Anchorage

David Booth, Associate Professor of Religion and Director of the Center for Integrative Studies, St. Olaf College

Sarah Bradford, Vice President, Product Management, eCollege

Barbara Cambridge, Vice President of Fields of Inquiry and Action, American Association of Higher Education

Darren Cambridge, Assistant Professor of Internet Studies and Information Literacy, George Mason University

George Calvert, Senior Vice President of Product Development, Blackboard Inc.

Jacob Chacko, Associate Dean and Professor of Marketing, Clayton College and State University

Helen Chen, Research Scientist, Evaluation, Stanford Center for Innovations in Learning

Melissa Chotiner, Public Relations Manager, Blackboard Inc.

Christopher Clapp, President, ANGEL Learning

Chris Coppola, President, r•smart group

Nikki Davis, Director, lowa State University Center for Technology in Learning and Teaching

Karen Gage, Vice President of Marketing, WebCT

Elizabeth Griego, Associate Director, Western Association of Schools and Colleges

Steve Griffin, Director, European IMS Network

Toru liyoshi, Senior Scholar, Director, Knowledge Media Lab

Ali Jafari, Director of the CyberLab, Indiana University Purdue University Indianapolis

Kathi Ketcheson, Director, Institutional Research \& Planning, Portland State University 
Susan Kahn, Director of the Office of Institutional Effectiveness, Indiana University Purdue University Indianapolis

Tom Lewis, Director, The Catalyst Group, Educational Partnerships and Learning Technologies, University of Washington

Stephanie Lisella, Project Coordinator, American Association of Higher Education

Patricia McGee, Assistant Professor of Instructional Technology, University of Texas at San Antonio

Phil Miller, E-Portfolio Project Manager, ANGEL Learning

John Moore, Director, Educational Technologies, Virginia Tech

Judith Patton, Director, University Studies, Portland State University

Barb Ross, Chief Operating Officer, WebCT

Paul Ross, Manager, Faculty Technology Resource Center, University of Denver

Janet Schnitz, Associate Dean, Teachers College, Western Governors University

Peter Seldin, Distinguished Professor of Management Emeritus, Pace University

Sutee Sujitparapitaya, Director of Institutional Studies, California State University, Sacramento

Neal Topp, Professor, University of Nebraska Omaha College of Education

Ed Walker, CEO, IMS Global Learning

Kathleen Blake Yancey, Pierce Professor of Professional Communication, Clemson University 